\title{
Me, environmentalist
}

\author{
Tarzan! Or Rousseau Among the Waziri \\ Quai Branly Museum, Paris, France \\ Until 27 September
}

Summer visitors to Paris might hear Tarzan's distinctive roar above the sound of traffic. The subject of an exhibition at the city's Quai Branly Museum (Musée du Quai Branly), the fictional loin-clothed hero provides possibly the most oblique take on Darwinism seen during the bicentennial year.

Tarzan! Or Rousseau Among the Waziri uses this cultural icon to examine depictions of the African jungle and the relationships between humans, apes and other animals in it. What is surprising, on rereading Tarzan of the Apes almost a century after its first appearance in the October 1912 issue of US magazine The AllStory, is author Edgar Rice Burroughs's evident interest in nature versus nurture. He studied $O n$ the Origin of Species closely.

"I was mainly playing with the idea of a contest between heredity and environment," Burroughs wrote in Writer's Digest in 1932. He selected an infant child "at an age at which he could not have been influenced by association with creatures of his own kind" and placed him in "an environment as diametrically opposite that to which he had been born as I might well conceive".

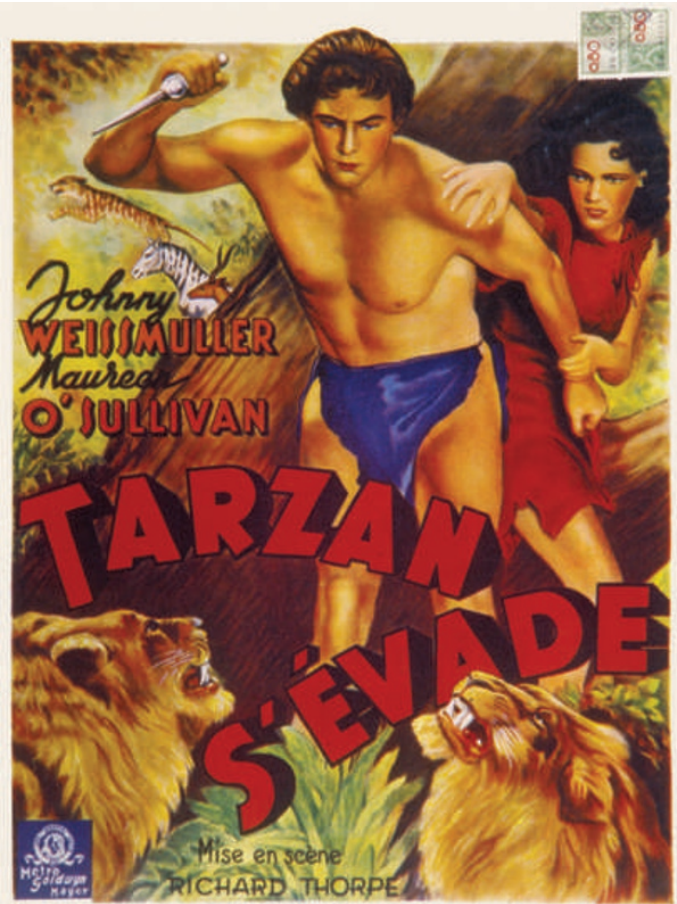

Early ecowarrior? The exhibition examines film depictions of the African jungle and its inhabitants through Tarzan.
Tarzan was instantly popular. The tale of this aristocratic hero, the orphaned son of John Clayton (Lord Greystoke) and his wife Lady Alice, raised by the female ape Kala whose own infant had been killed, retains its appeal. Burroughs turned his writing into a business, producing 22 Tarzan adventures that led to 42 feature films, 15,000 comic books, and innumerable cartoons and television series.

It is surprising that France's national museum of non-European indigenous art, cultures and civilizations, with its enormous collection of African, Asian, Oceanic and American artefacts, has devoted an exhibition to Tarzan. "Our exhibition allows the public to discover how Tarzan, an icon of popular culture, was created and to decipher the heroic myth that he embodies," says exhibition curator Roger Boulay, an ethnologist.

The subtitle 'Rousseau Among the Waziri' links Tarzan to the eighteenth-century philosopher Jean-Jacques Rousseau's ideas on human perfectibility, in evolving from a primitive natural state to civilized society. The Paris exhibition reminds us that Tarzan was instructed in etiquette and was taught to speak French by Lieutenant Paul d'Arnot, the naval officer he had rescued from African cannibals. Later, as they walked up the coast together for four weeks to reach a river port, Tarzan metamorphosed under d'Arnot's instruction into the white-clad Monsieur Tarzan, unfazed by cutlery and dinner conversation.

The exhibits include ethnographic objects and stuffed African animals from several French museums; as well as original comic strips and film and television clips, which fuelled the public's vision of a fantasy Africa. Juxtaposing the comic-book imagery with less familiar African artefacts shows that our understanding of Tarzan owes as much to drawings by Tarzan illustrators Burne Hogarth and Joe Kubert, and to film actors including Frank Merrill and Johnny Weissmuller, as it does to Burroughs' text.

The exhibition redefines Tarzan as a twentieth-century ecowarrior, ahead of his time in fighting animal poachers and slave traffickers. It encourages us to look beyond clichés to what it is to be human; part of the animal kingdom but with the capacity to reason — and to take considerate actions. Colin Martin is a writer based in London. e-mail: cmpubrel@aol.com

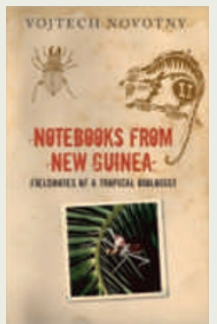

In Notebooks from New Guinea (Oxford University Press, 2009), tropical biologist Vojtech Novotny describes vividly what it is like to work deep in the malaria-infested Papuan rainforest. Sharing his personal experiences of setting up a research station in this remote and lawless place, he reflects on the clash between the cultures of Papua New Guinea and Europe. Novotny is humbled by the folk knowledge of local tribes, and colourfully describes their customs and interactions with loggers and conservationists.

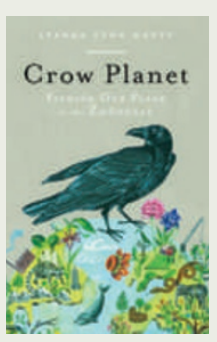

The urban wilderness is the home of naturalist Lyanda Lynn Haupt. In Crow Planet (Little, Brown, 2009), she weaves into a series of stories the science, history and mythology of these independent and charismatic birds. Crows are noisy, boisterous and quick to learn and adapt to urban life. Through her closely observed portraits of these creatures, Haupt urges us to pay more attention to nature within our city landscapes.

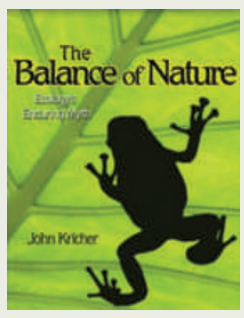

John Kricher tackles the history of ecology in his new book, The Balance of Nature (Princeton University

Press, 2009). Arguing that nature is far from poised and is constantly in flux, he asks why we hold on to the idea of ecological balance. He finds that the roots of our desire for order are ancient, and predate Aristotle. But solutions to today's environmental problems require us to take a more dynamic view of nature. Ultimately, he explains, evolution is the driver of natural systems.

J.B.

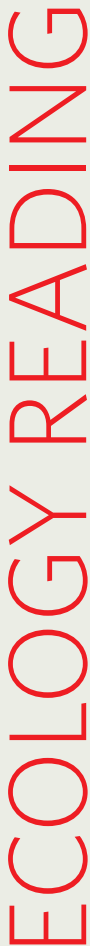

